\title{
7 EGGARS, SCAMMERS, DISCRIMINATED AGAINST BY THE WHOLE OF EUROPE: ROMANIA'S ROMA IN FINNISH TABLOIDS, 2008-2011
}

\section{Kari Alenius}

University of Oulu, E-Mail: kari.alenius@oulu.fi

\section{Acknowledgments}

This paper has been presented at the Third International Conference on Nordic and Baltic Studies in Romania: European Networks: the Balkans, Scandinavia and the Baltic World in a Time of Crisis hosted by the Romanian Association for Baltic and Nordic Studies and Valahia University of Târgoviste, and sponsored by the Romanian National Research Council, May 25-27, 2012.

\begin{abstract}
:
The unrestricted movement of EU citizens from one country to another has been one of the fundamental principles of the Union. On the other hand, this issue has also attracted criticism, particularly from the radical right and so-called populist parties, or the supporters of these movements. Part of the population of Europe regards immigration and the unrestricted movement of people as a threat to the stability and prosperity of their own society. Through these critical perspectives, permanent immigration is viewed as a larger problem, as its effects on the host countries are more permanent than in the case of temporary residence. Through the same perspectives, the short-term but uncontrolled stay of foreigners is often linked to crime. This study concentrates on what kind of image a significant part of the Finnish media has given of a recent case of the foreigners that have attracted large attention in the country.
\end{abstract}

\section{Rezumat:}

Circulația liberă a cetățenilor Uniunii Europene dintr-o țară în alta a reprezentat unul dintre principiile fundamentale ale Uniunii. Pe de altă parte, această problemă a atras, de asemenea, critici, mai ales din partea radicalilor de dreapta şi aşa-numitelor partide populiste sau a simpatizanților acestor mişcări. O parte a populației Europei priveşte imigrația şi circulația liberă a persoanelor ca o amenințare pentru stabilitatea şi prosperitatea societății lor. Din această perspectivă, imigrația permanentă este văzută ca o problemă mai mare, după cum efectele sale asupra țărilor gazdă sunt mai durabile decât în cazul şederilor 
temporare. Potrivit aceloraşi puncte de vedere, şederea scurtă dar necontrolată a cetățenilor străini este adesea legată de criminalitate. Acest studiu se concentrează asupra imaginii pe care a creat-o o semnificativă parte din mass-media finlandeză unui caz recent al străinilor care au atras atenția în această țară.

Keywords: Roma, newspapers, public debate, image, stereotypes, Finland, Romania

\section{Introduction}

Roma are one of the groups whose movement within the EU has attracted much attention in recent years. Roma live in all EU countries, but in absolute and relative terms, most of them are in eastern Central European countries and in the Balkans. In the case of Roma populations, perhaps Romania's Roma, many of whom have moved to the north and to Western Europe within the last few years, have caught the most international attention. This phenomenon was a direct consequence of the fact that Romania's inclusion as an EU member in 2007 resulted in much greater possibilities for movement. ${ }^{1}$

This article examines what kind of image Finnish tabloids have presented of the Roma issue during the years 2008-2011 and why the image was a certain kind. This subject matter has been unexplored so far. However, this subject is important as the media is of great significance in regards to the formation of human opinions, attitudes and worldviews. Tabloids, the so-called yellow press, are, in turn an important research topic within the media as these papers are quite popular and they are visible in the everyday lives of ordinary people, for example in supermarkets, bus and train stations kiosks. Their news coverage is also sensation-seeking and has a way of dramatizing things. Therefore, it can be assumed that people pay attention to tabloids and they can affect people, although a large portion of the population.05.at the same time take a more skeptical attitude towards the contents of tabloids than they do to the articles of "more serious" newspapers. ${ }^{2}$

\footnotetext{
1 Council of Europe: Commissioner for Human Rights, Recent Migration of Roma in Europe, 10.12.2008, http://www.unhcr.org/refworld/docid/4a703c2a2.html: 11-13, 30-35.

2 The general characteristics of tabloids; see for instance, Colin Sparks, "Introduction. The Panic over Tabloid News," in: Tabloid Tales. Global Debate over Media Standards, eds. Colin Sparks and John Tullock (Lanham: Rowman \& Littlefield, 2000), 1-40; Herman Wasserman, African Expressive Cultures. Tabloid Journalism in South Africa: True Story! (Bloomington: 88
} 
In Finland, two tabloids are published, the Ilta-Sanomat and Iltalehti. This study has systematically analyzed the contents of each paper during the years 2008-2011 (both electronic and paper version, the contents of which are in most cases identical). This time frame is based on a broader familiarization with the material from the beginning of the early 2000s onwards: it shows that Roma related writings have specifically appeared during the years 2008-2011, but hardly before this time. Circulation statistics show that during 2010, the Ilta-Sanomat was Finland's second most popular paper that appeared every day (with a circulation of approximately 150,000). According to the same statistics, the Iltalehti is in fifth place (with a circulation of approximately 107,000). To uncover the specific characteristics of these tabloids, the content of one "ordinary" newspaper has been systematically examined for this same time period, to which it is possible to compare the tabloids. The Turun Sanomat, similar in its circulation statistics, has been chosen for this (fourth in circulation rankings, approximately 107,000). ${ }^{3}$ Two other Finnish daily newspapers with a broad circulation, the Aamulehti and Helsingin Sanomat, have been omitted as their electronic versions are not freely available.

The main research question of this study is: what kind of image have the Ilta-Sanomat and Iltalehti created, particularly of Romania's Roma, and why is this image as it is. The sub questions are: what kinds of elements is this image built of and has it changed between the years 20082011 (and if so, why is this so). Of quantitative research methods, the method of analyzing writing intensity has been used, in this case of the distribution of writing over time as a whole, on an annual and on a quarterly basis. Qualitatively, the contents of writing and the change in tone has been examined, with particular attention paid to the selection of themes used, both in news headlines and in the rhetoric used in texts. With these as explanatory factors, the editorial (tabloid) culture and presumed goals of the papers have been are taken into account particularly. Newspapers do not merely seek to describe "reality", but at the same time, in their writing they seek to fashion it in their desired direction. For tabloids, which largely rely on single copy sales, anticipating the

Indiana University Press, 2010), 14-23. See also David Ratz, "The Study of Historical Images," Faravid 31 (2007): 218-220.

3 (Circulation statistics in Finland 2010) "Suomen 10 suurinta sanomalehteä levikin mukaan," http:/ / www.sanomalehdet.fi/index.phtml?s=119, accessed 22.11.2011. 
expectations of readers and piquing the interest of potential buyers are also highly important factors guiding actions. ${ }^{4}$

\section{Quantitative analysis}

Chart 1: The quantitative distribution of articles concerning the Roma in Ilta-Sanomat (1-3 = January-March; 4-6 = April-June; 7-9 = July-September; 10-12 = October-December)

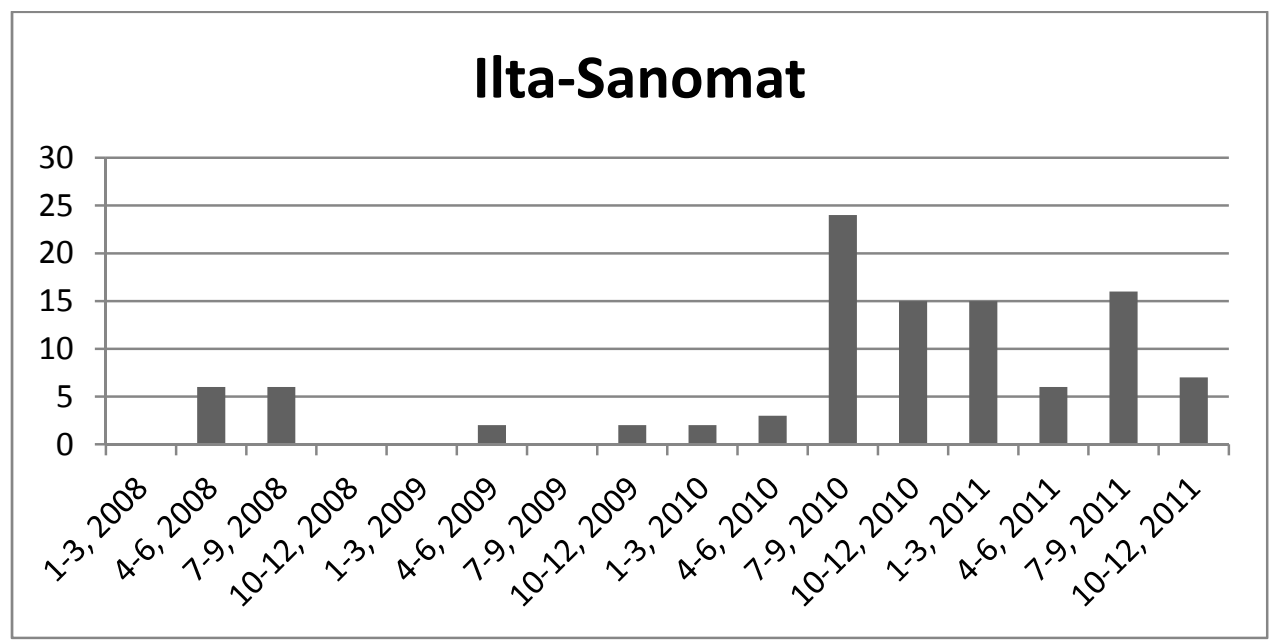

4 Wasserman 2010, 17-20. 
Chart 2: The quantitative distribution of articles concerning the Roma in Iltalehti (1-3 = January-March; 4-6 = April-June; 7-9 = July-September; 10-12 $=$ October-December)

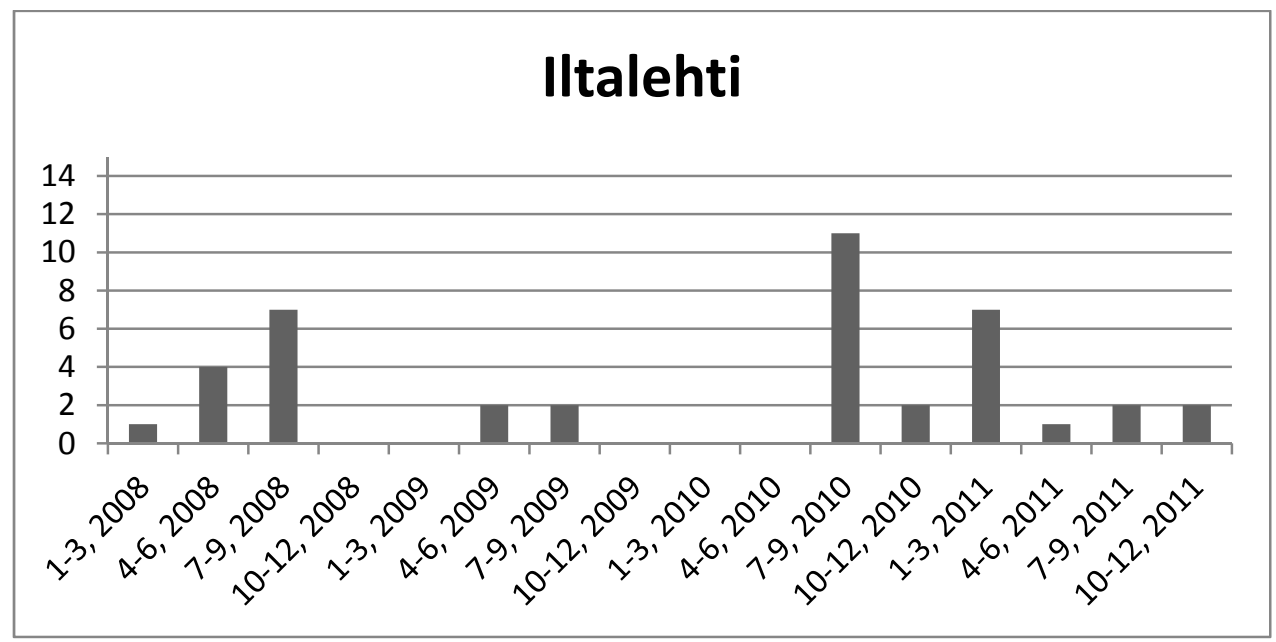

Chart 3: The quantitative distribution of articles concerning the Roma in Turun Sanomat (1-3 = January-March; 4-6 = April-June; 7-9 = JulySeptember; $10-12$ = October-December)

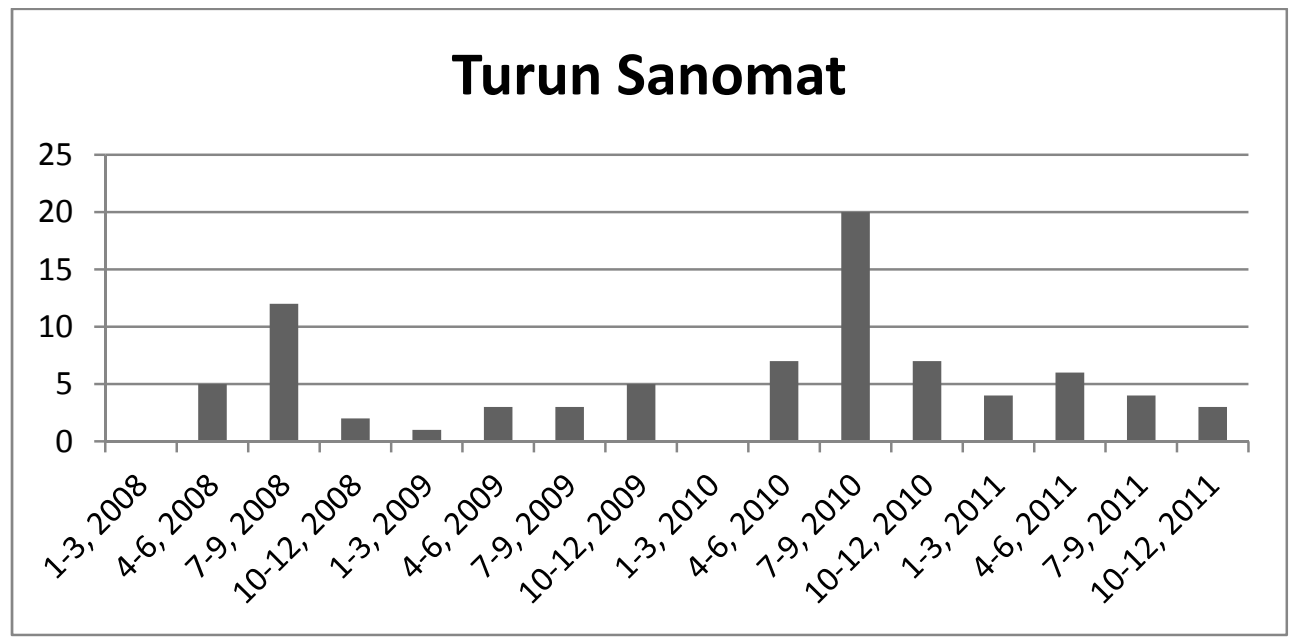

Charts 1-3 present the quantitative distribution of articles concerning the Roma in various newspapers on a quarterly basis. In the case of tabloids, it is evident that the intensity of writing and the changes 
occurring within it are almost identical from the beginning of 2008 until the fall of 2010. From the fall of 2010 to the fall of 2011 the Ilta-Sanomat's interest in writing about the topic has remained slightly higher than that of the Iltalehti. In drawing conclusions in this context it is important to note that the Ilta-Sanomat's way of publishing news changed just during the latter half of 2010. From then on, the Ilta-Sanomat has tended to publish several news pieces on a topic, up to a dozen separate pieces of news on the same day, if there has been rapid development in a series of events that have been of interest to the paper. This also largely explains the noticeable differences in the volume of articles concerning the Roma issue. For instance, on August 30, 2010, the Ilta-Sanomat published seven separate pieces of news that dealt with the situation of Roma in Helsinki. ${ }^{5}$ The next day, the Ilta-Sanomat published three more pieces of news. ${ }^{6}$

During the same days, the Iltalehti published only one (larger) news item on the same event. ${ }^{7}$ If separate news pieces published on the same or consecutive days are interpreted as one comprehensive writing, the difference between the tabloids disappears almost entirely. In other words, the difference can be considered ostensible to some extent, and can be partly attributed to publication techniques. On the other hand, the publication of many separate news items on the same day indicates that the editorial board felt a great deal of interest in the issue. It can therefore be interpreted that the Ilta-Sanomat's interest in the Roma issue had already grown somewhat larger than that of the Iltalehti in late 2010, and remained such until the present. The difference can be explained by the Ilta-Sanomat's change in approach - the increase in the critique of the Roma - which will be described later in this article.

In the case of the Turun Sanomat, it can be seen that the intensity of writing is broadly comparable to similar tabloids, but the articles are a little more evenly distributed over various periods. In common with the tabloids

\footnotetext{
5 "Romanit häädettiin - paikalla kymmeniä poliiseja"; "Kuvagalleria: Tuijotuskilpailu Senaatintorilla - poliiseilla iso operaatio romanien takia"; "Toinen teltta pystyyn - poliisit alkavat hermostua"; "Nyt puhuu häädettävä romani"; "Poliisi hermostui romaneille: Teillä on 20 minuuttia aikaa"; "Tuijotuskilpailu ohi - romanit luovuttivat!"; "Uusi käänne: Romanit Tuomiokirkkoon sisälle - poliisit perässä", Ilta-Sanomat 30.08.2011.

6 "Romanit luovuttivat sateessa: Kaikki teltat purettiin - katso kuva"; "Poliisi ei ole kuullut uudesta romanileiristä Helsingissä"; "Romanit katosivat - poliisi ymmällään", Ilta-Sanomat 31.08.2011.

7 "Sade hätisteli romanit Senaatintorilta", Iltalehti 31.08.2011.

92
} 
is the fact that the Roma issue first became a major news item in the spring of 2008 and remained such until the early fall of the same year. Thereafter, there was a decrease in writing until, in the summer of 2010 the intensity of writing again increased significantly. After this peak in writing, interest in the issue has decreased slightly but has remained at a fairly high level. The more even time distribution of the Turun Sanomat's articles is explained by the different nature of the paper - in question is a "normal" newspaper. It enables the processing of themes in the paper even when there are no background events of the same or previous day awaking interest. This problematic will also be returned to later in this article.

It is logical that in all of the papers concerning Roma, the beginning of writing occurred in the spring of 2008 as at this time the first significant number of Romanian Roma arrived in Finland. Begging and peddling meant that Roma were very visible on the street scene and not only attracted attention but also a wide range of emotions. They usually returned to their home country for the winter, in which case there was no specific news regarding the issue. In 2009 slightly fewer Roma arrived and the issue did not have the same kind of particular novelty as it did the previous year. Thus, the decrease in the intensity of writing is understandable. Once again in 2010, the Roma arrived in large numbers and were linked with several high-profile individual events. ${ }^{8}$ Their return to Romania for the winter also turned out to be problematic, and since then, the ongoing abuses related to their residence have also been under discussion more than in the past. Therefore, the intensity of writing rose during the fall of 2010, and for the first time, remained moderately high over the winter.

\footnotetext{
8 “Kerjäläisten määrä lähes entisellään”, Helsingin Sanomat 4.06.2009; Sisäministeriö. Kerjäämisen kieltämistä selvittävä työryhmä. Loppuraportti, http://www.intermin.fi/intermin/biblio.nsf/A76D52A8F876DE07C22577B4001BCE18/\$fil e/312010.pdf, accessed 30.03.2012.
} 
Chart 4: Yearly distribution of writings according to the tone towards the Roma in Iltalehti

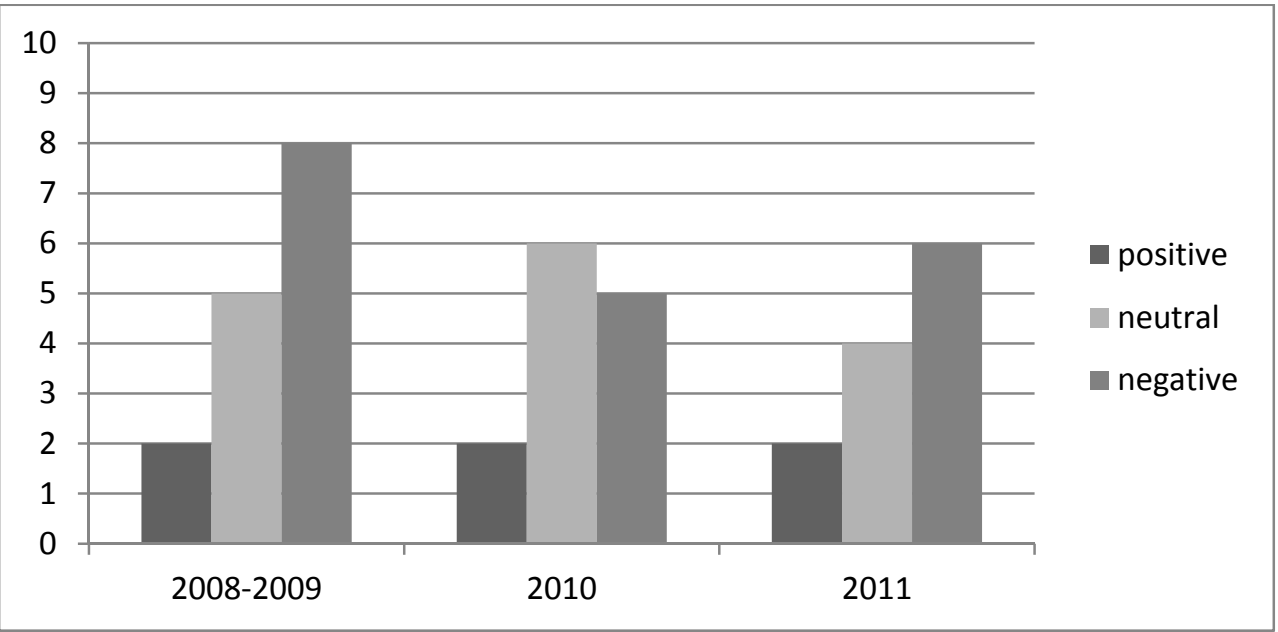

Chart 5: Yearly distribution of writings according to the tone towards the Roma in Ilta-Sanomat

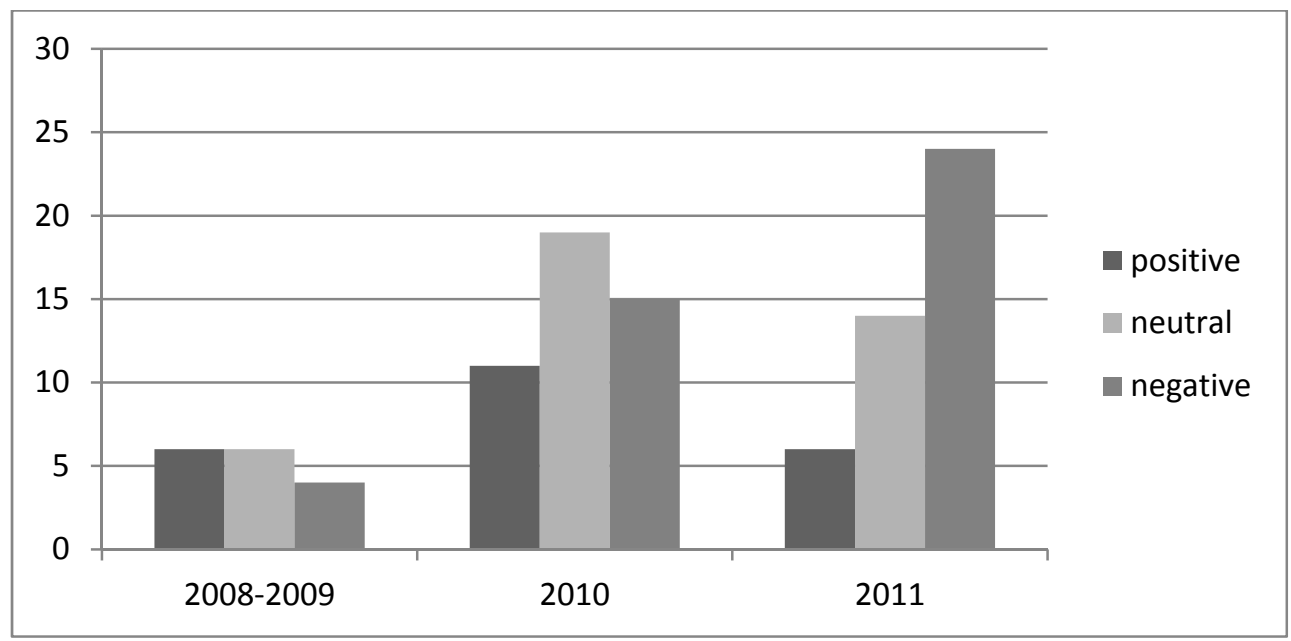


Chart 6: Yearly distribution of writings according to the tone towards the Roma in Turun Sanomat

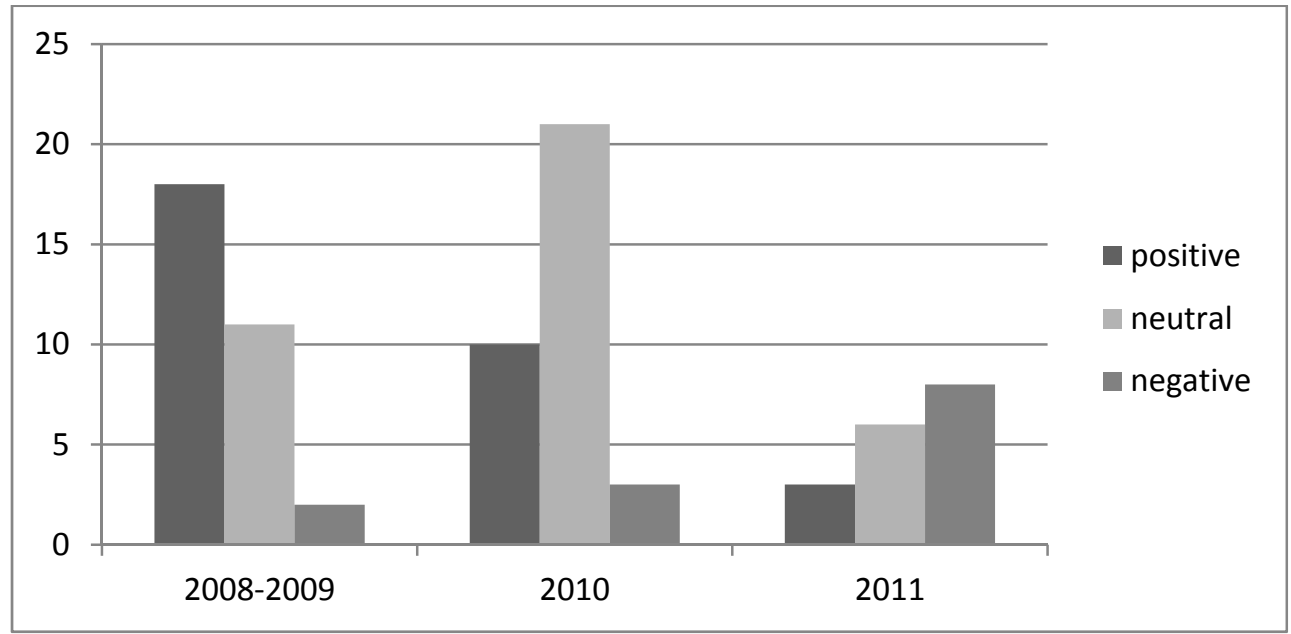

Charts 4-6 show the yearly distribution of articles concerning the Roma in different newspapers, according to what kind of main tone there was towards Roma. The basic division is positive - neutral - negative, and articles that have both negative as well as positive comments without either being dominant are included in the neutral category. Articles from the year 2009 are included together with those from 2008, as the number of articles from 2009 is so few that a separate chart is not appropriate. In particular, the number of articles in tabloids during 2009 (Ilta-Sanomat: 4, Iltalehti: 3) are so few that drawing conclusions is impossible. The value of an individual article is too great from the perspective of statistical analysis. Of course, it is true that the number of articles from other years are also so few that the use of actual statistical mathematical methods would be appropriate. However, these amounts are sufficient as directional indicators for drawing conclusions regarding the change in tone in these articles.

Given the sensation seeking nature of tabloids, it is perhaps according to expectations that tabloids have always had a more negative stance towards the Roma than the Turun Sanomat, in comparison. There is a particularly large difference during the years 2008-2010. Almost during this entire time, tabloids have clearly published more negative than positive or sympathetic articles in regards to the Roma. There has been roughly the 
same amount of neutral articles as negative, but during 2011 the balance has shifted to the negative side. In 2011, in both of tabloids the number of articles critical of the Roma has been equal to or slightly greater than the total number of neutral and positive articles. Therefore, the trend has been towards the negative, and already during the years 2008-2010 the average attitude has been between the negative and neutral.

In comparing these tabloids to each other, it is evident that the number of positive articles has, with one exception, been the smallest of these three categories in both papers. In the case of the Ilta-Sanomat, in the chart 4, which portrays the years 2008-2009, the number of positive and neutral articles is equal to and greater than the number of negative ones. However, it is important to note that of the positive articles, most of them (4 out of 6) were published during the spring of 2008 when, for the first time, issues regarding the Roma came to the attention of the media. ${ }^{9}$ Thus, the first reaction of Ilta-Sanomat's editorial board differed from that of the Iltalehti. At the very beginning, the attitudes of the Ilta-Sanomat's editorial board towards Roma consisted mainly of curiosity and a mild benevolence. However, already during late 2008, the editorial board of the Ilta-Sanomat took the same kind of general stance, between neutral and negative, towards the Roma, and has kept it ever since. Excluding their first reaction, the attitude of tabloids towards Roma has therefore been very similar throughout the entire period studied.

A dramatic change has instead taken place in the general attitude of the Turun Sanomat, the comparison point. During 2008 the attitude of the Turun Sanomat towards Roma was strongly positive and only in a few articles did it take a critical view of them. During 2009, the number of positive and neutral articles changed to roughly equal, but the number of negative articles remained very few. During 2010 the balance between positive and neutral articles clearly changed to prefer the latter, and the main tone can be described as neutral. Until then, the tone was initially positive and was afterwards, between the positive and neutral. During 2011, the writing of the Turun Sanomat regarding Roma has clearly moved in the direction in which the trend has been previously. Negative articles

\footnotetext{
9 "Romanijärjestöt: Syrjintä yhä arkea Euroopassa" Ilta-Sanomat 7.04.2008; "EU varoitti Italiaa romanien syrjinnästä" Ilta-Sanomat 20.05.2008; "Halonen keskustelee Romaniassa romanien oloista" Ilta-Sanomat 21.05.2008; "Romanit vaativat loppua vainolle Italiassa" IltaSanomat 8.06.2008. 
have become the largest group, almost as large as the other two categories combined. In short, during the years 2008-2010 the Turun Sanomat clearly wrote more positively of the Roma than tabloids, and particularly refrained from publishing negative comments. Specifically during 2011, the publication of critical comments in the Turun Sanomat has increased strongly and the difference of tone in writing in comparison to the tabloids has vanished.

\section{Qualitative analysis}

When analyzing the content and tone of various articles in different newspapers, three different periods can be differentiated from each other. The first covers the period from the spring of 2008 until the spring of 2010. The second period, which differs from the preceding and following periods in a few essential ways, extends from the summer of 2010 roughly to the end of the same year. The year 2011 forms its own, different period. As noted above, the initial reaction of the Ilta-Sanomat's editorial board differed from that of the Iltalehti. When the Roma issue first arose in Finland as a topic of discussion, both tabloids immediately published news articles in a critical tone that wondered at the begging and peddling of the Roma, ${ }^{10}$ which differed from what people were used to in Finland. Generally, beggars had not been seen in Finland before this, and in addition, some individual cases, such as stopping passing cars on motorways were also illegal, and therefore attention-grabbing. Therefore, already in the spring of 2008, both tabloids began to create an image of the Roma as a strange and different group, which clearly differed from the Finnish population.

On the other hand, the image was balanced by news that had a mainly neutral tone. These writings described the status of Roma elsewhere in Europe, ${ }^{11}$ likely to give some background to the events in Finland. The poor living conditions of Roma and the fact that there was discrimination

\footnotetext{
10 "Romanialaisvarkaat rikastuvat lapsiorjilla", Iltalehti 25.01.2008; "Romanikerjäläiset pysäyttelevät autoja Varsinais-Suomen teillä", Ilta-Sanomat 16.04.2008;"EU-kerjäläisten uusin kikka - turvapaikkahakemus", Iltalehti 25.06.2008; "Jo 16 taskuvarasta jäänyt kiinni Helsingin keskustassa", Ilta-Sanomat 17.07.2008.

11 "Berlusconi ryhtyy kiristämään maahanmuuttolakia", Iltalehti 14.05.2008; "Halonen keskustelee Romaniassa romanien oloista", Ilta-Sanomat 21.05.2008; "Romania ei aio rajoittaa kerjäläisten matkustusoikeutta", Iltalehti 9.06.2008; "Romania ei rajoita kerjäläisten matkustusoikeutta", Ilta-Sanomat 9.06.2008.
} 
against them in many areas were brought forth, although even the tone of these articles was generally not sympathetic towards the Roma. Only a few articles took the side of the Roma. In this case, the news in question was, among others, one which told of systematic discrimination or the attacks of Eastern European extreme right-wing groups against the Roma. ${ }^{12}$ When the "first wave" of Roma left Finland late in the fall of 2008, interest in this issue almost came to an end. From 2009 until the spring of 2010, the Roma only made the tabloid news a couple times, when something unusually dramatic was occurring elsewhere in Europe: for example, in April 2009, allegations that the police in Slovakia had tortured the local Roma were reported. ${ }^{13}$

The writing style of the Ilta-Sanomat and Iltalehti was typical of the tabloid press. In the case of the Roma, only news regarding dramatic or unexpected events was published. The situation of the Roma outside Finland was followed only sporadically, presumably on the assumption that single copy buyers were not interested in things that took place far away from Finland, unless they were associated with a particular drama. The writing style of the Turun Sanomat was clearly different during the first period of examination. In a few news pieces, the Turun Sanomat also reported of unexpected events such as attacks against the Roma elsewhere in Europe, ${ }^{14}$ but by far the largest numbers of writings were related to other issues than individual daily cases. Articles that were clearly critical of the Roma were generally not published, but during the years 2008-2009, the material on the Roma published by the Turun Sanomat consisted of neutral, sympathetic or background articles on the Roma, which comprised over ninety percent. Overall, the tone of writing in Turun Sanomat articles was clearly more focused on discussing and describing the general situation of the Roma. ${ }^{15}$ The Turun Sanomat also more regularly and actively followed

\footnotetext{
12 "Romanijärjestöt: syrjintä yhä arkea Euroopassa", Ilta-Sanomat 7.04.2008; "Romanit vaativat loppua vainolle Italiassa", Ilta-Sanomat 8.06.2008; "Kansalaisliike: romanit jäämässä heitteille", Iltalehti 24.07.2008; "EU ja romanit pohtivat keinoja romanien olojen parantamiseksi", Iltalehti 16.09.2008.

13 "Slovakialaisia poliiseja syytetään romanilasten kiduttamisesta", Iltalehti 8.04.2009; "Slovakialaisia poliiseja syytetään romanilasten kiduttamisesta", Ilta-Sanomat 8.04.2009.

14 "Hindujohtaja vetoaa Euroopan romanien puolesta", Turun Sanomat 5.09.2008; "Uusnatsit yrittivät hyökätä romanilähiöön Tshekissä", Turun Sanomat 19.11.2008.

15 "Romanin vaikea saada turvapaikkaa Suomesta", Turun Sanomat 25.06.2008; "Kerjääminen ei kumpua romanikulttuurista", Turun Sanomat 21.07.2008; "Romanit kelpaavat vaaliaseeksi", Turun Sanomat 28.09.2009.

98
} 
discussion regarding the status of the Roma elsewhere in Europe than the tabloids. ${ }^{16}$ This kind of reflective material regarding other than current-day politics was no doubt easier to publish in a "normal" newspaper such as the Turun Sanomat, which did not have to attract buyers with sensationalism every day.

Based on the material published by the Turun Sanomat also, the image of the Roma as a "different" group already formed during the first period. However, rejection and the emphasis of negative phenomenon were not related to this discourse of otherness to the same extent that they were in tabloids. At the same time, the problems caused by Roma in Finland became a minor side issue of the whole of material published during the first period, in contrast to the tabloids. It is not possible to assess what kind of image readers of the paper formed on the basis of these articles, but at least it can be said that until the spring of 2010, material published by the Turun Sanomat did not lend support to the creation of negative images. Rather, it appears that the editorial board of the Turun Sanomat wanted to address the situation of the Roma in a considerate way, and in a positive or at least a neutral light. On a number of occasions the newspaper found that the Roma were to be treated equally and fairly and that there was a lot of room for correction in the current weak position of the Roma. ${ }^{17}$ In tabloids, such ethical statements and specific efforts to maintain a journalistic balance were lacking for the most part.

During the summer of 2010, the number of articles concerning the Roma rose dramatically. The theme of most articles during the summer and early fall was France's decision to deport part of the Roma who had come from Romania back to their homeland. This led to extensive debate across Europe. Those that took a critical attitude towards the Roma regarded France's decision as being correct, but opinions on the other side of the field of the deportation issue regarded this as a case of discrimination against the Roma and a breach of their human rights. Debate on the issue gradually

\footnotetext{
16 "EU haluaa kitkeä romanien syrjintää", Turun Sanomat 2.07.2008; "Rasismi on EU-maissa luultua yleisempää", Turun Sanomat 22.04.2009; "Romaneja vainoava ääriryhmä Jobbik on voittanut jalansijaa Unkarissa", Turun Sanomat 27.06.2009.

17 "Romanin vaikea saada turvapaikkaa Suomesta", Turun Sanomat 25.06.2008; "Kerjääminen ei kumpua romanikulttuurista", Turun Sanomat 21.07.2008; "Aktivistit syyttävät avustusjärjestöjä selän kääntämisestä", Turun Sanomat 25.07.2008; "Rasismi on EU-maissa luultua yleisempää", Turun Sanomat 22.04.2009; "Rasismi kytee vahvana Italiassa", Turun Sanomat 7.10.2009.
} 
faded away during the fall. The European Parliament condemned the deportations, but no legal solution to the issue was obtained. ${ }^{18}$

Finnish tabloids mainly took a neutral stance towards the events in France. Perspectives from either side of the controversy were brought forth roughly as frequently and to the same extent in terms of column space. On the other hand, it is evident that the debate was mostly over the fairness of deportation. The news always made it clear that the Roma were staying in France illegally and had established illegal camps. In addition, according to the news, the Roma begged and stole and their activities were related to elements of organized crime. Thus, according to the image transmitted to readers, the problems caused by the Roma were extensive and real. ${ }^{19}$ However, France's decision to deport them as a group was legally and ethically questionable since all of the deportees had not been convicted in court. Critics also accused France of a general stigmatization of the Roma. ${ }^{20}$

In its coverage of the Roma issue in France, the Turun Sanomat differed from the tabloids in the same way as it had for about two years. Once again the Turun Sanomat published several articles that were unrelated to the politics of the day, which considered the general improvement of the situation of the Roma, both in their homeland of Romania (and Bulgaria) as well as in Western Europe. ${ }^{21}$ As well, articles of the Turun Sanomat concerning human rights aspects and concerns about discrimination against Roma across Europe were more apparent than in tabloids, in estimation according to their column space. ${ }^{22}$ However, this

18 "EU tuomitsi Ranskan romanikarkotukset - Ranska närkästyi", Ilta-Sanomat 9.09.2010; "Parlamentilta näpäytys Ranskalle", Turun Sanomat 11.09.2010; "EU aikoo luopua Ranskan vastaisista oikeustoimista romaniasiassa", Iltalehti 19.10.2010.

19 "Ranska aikoo hajottaa romanileirit", Iltalehti 28.07.2010; "Ranskan poliisi aloitti romanileirien tyhjentämisen", Ilta-Sanomat 6.08.2010; "Ranskan poliisi aloitti romanileirien tyhjentämisen", Iltalehti 6.08.2010; "Ranska on sulkenut jo 40 romanileiriä", Ilta-Sanomat 12.08.2010; "Lähes puolet ranskalaisista tukee romanien karkotusta", Iltalehti 25.08.2010.

20 "Kritiikki Ranskan romanikarkotuksen ympärillä kasvaa", Iltalehti 19.08.2010; "Ranska aloitti kiistellyt romanien karkotukset", Ilta-Sanomat 19.08.2010; "Ranska jatkaa romanien karkotuksia, EU:lta vaaditaan kannanottoa", Iltalehti 26.08.2010; "YK moittii Ranskaa romanien kohtelusta", Ilta-Sanomat 27.08.2010.

21 "Amnesty vaatii parempaa kohtelua romaneille", Turun Sanomat 17.05.2010; "Romanit määritellään yhä ongelmalähtöisesti", Turun Sanomat 3.07.2010; "Ruotsi karkottaa romanikerjäläisiä ulkomaalaislain perusteella", Turun Sanomat 31.07.2010; "Romanian kerjäläiset eri asia kuin romanit", Turun Sanomat 10.08.2010; "EU patistaa jäsenmaita tukemaan romaneita", Turun Sanomat 13.10.2010.

22 "Suomen romanit vastustavat kerjäämisen kieltoa", Turun Sanomat 21.06.2010; "Missä valtaväestö ja romanit voivat luontevasti tutustua toisiinsa", Turun Sanomat 6.07.2010; 100 
humane and understanding attitude towards the Roma also began to deteriorate in the Turun Sanomat when domestic events in articles concerning the Roma rose to predominance in the late fall of 2010.

In Finland, a significant change in direction in the debate over the issue of the Roma occurred in the fall of 2010 when Minister of the Interior Anne Holmlund publicly expressed her belief that beggars should be gotten rid of. Around the same time, the Ministry of the Interior established a commission to examine how begging could be legally prohibited. ${ }^{23}$ When the highest quarters of the state considered beggars, or Romanian Roma in Finland a problem, it undoubtedly confirmed a negative attitude towards Roma, at least among those who already had negative attitudes towards them. This unwelcoming attitude gained a sort of legitimate stamp. Both Finnish tabloids can be included in this more critical than sympathetic group. The tone of the Iltalehti's articles had already been clear earlier, and during the fall the attitude of the Ilta-Sanomat also became more negative, even slightly more negative than that of the Iltalehti. ${ }^{24}$ The Ilta-Sanomat's change in writing activeness also appears to have been linked to this change in attitude. When the editorial board of the Ilta-Sanomat decided to make these problems more explicit, it apparently sought to use the subject matter more effectively in creating news that had a more scandalous tone. In a sense, repeatedly returning to the subject was a somewhat consistent choice, at least as long as the problematic parts were clearly newsworthy and they had not been discussed too many times. One subject matter could be used to attract readers for a while, but sooner or later new themes that had the potential to appeal to buyers would have to be created.

Another event in the fall of 2010 that led tabloid articles in a more critical direction was related to the decision of the city of Helsinki to pay those Roma returning to Romania their return travel expenses (325-425

\footnotetext{
"EU:Ita vaaditaan kantaa Ranskan romanikarkotuksiin", Turun Sanomat 26.08.2010; "Sarkozy kosti romanikritiikin Luxemburgille", Turun Sanomat 15.09.2010.

23 "Holmlund Ylelle: Kerjäläisistä päästävä eroon!"; Ilta-Sanomat 18.09.2010; "Kerjääminen halutaan kieltää", Ilta-Sanomat 6.10.2010; "Vihreät ja asiantuntijat tyrmäävät kerjäämislakiesityksen", Turun Sanomat 7.10.2010.

24 "Holmlund Ylelle: Kerjäläisistä päästävä eroon!"; Ilta-Sanomat 18.09.2010; "Rikollisliiga pakotti romanilapsia kerjäämään ja varastamaan", Ilta-Sanomat 28.09.2010; "Romanit huijasivat 3,5 miljoonan tuet", Ilta-Sanomat 8.11.2010; "Romaniliiga iski raha-automaateilla Helsingissä", Ilta-Sanomat 13.11.2010; "Diakonissalaitos: Osa romaneista myönsi palaavansa", Iltalehti 28.11.2010; "Pakkastalvi ja lähtöraha karkottaneet kerjäläisiä", Iltalehti 17.01.2011.
} 
euros per family). Both tabloids reacted negatively to "Finnish tax money being pumped into" foreign beggars. ${ }^{25}$ It appears that this aroused strong criticism, particularly among the editorial board of the Ilta-Sanomat. Anger increased when, according to the news, some of the beggars took the money but did not immediately leave Finland. These types of real or suspected abuses were typical of the scandals that the tabloids were looking for. At the same time, the events likely confirmed the notion that the Roma were "scammers and criminals who exploited the unsuspecting Finns".

These types of doubts directly hit the vulnerable points of expectations regarding general equality. People are particularly sensitive to it if they feel that they have been treated unfairly in the allocation of material resources. The fact that someone gets the benefits without having to earn them or more than is reasonable for him is a great psychological burden for those who feel that they have received too little. The issue is made worse if those that have received too much are outside of one's own group, from whom one cannot soon or perhaps at all expect reciprocal favours in some other important situations. ${ }^{26}$ In the case of the Roma, the theoretical conditions of this negative scenario were met. An outside group that was experienced as alien, different, and strange apparently received money on the wrong basis and even abused this unjustified benefit.

The following spring and summer, tabloid journalism increasingly focused specifically on the perceived negative behavior of Roma beggars in Finland and elsewhere. Both papers published news according to which begging and peddling were related to organized crime and scamming.27

25 "Romanit ulos Suomesta - 325 euroa käteen", Ilta-Sanomat 25.11.2010; "Jouluksi kotiin Helsingin kaupungin piikkiin", Ilta-Sanomat 26.11.2010; "Diakonissalaitos: Osa romaneista myönsi palaavansa", Iltalehti 28.11.2010; "Osa romanikerjäläisistä jäikin Suomeen - 'auto on rikki'", Ilta-Sanomat 29.11.2010; "IL Romaniassa: Näin Suomessa kerjäävät elävät kotimaassaan", Iltalehti 7.01.2011; "Pakkastalvi ja lähtöraha karkottaneet kerjäläisiä", Iltalehti 17.01.2011.

${ }^{26}$ Kenneth J. Gergen and Mary M. Gergen, Social psychology (New York: Springer, 1986), 194220; Henry Tajfel and John Turner, "An Integrative Theory of Intergroup Conflict," in: The Social Psychology of Intergroup Relations, ed. W. G. Austin \& S. Worchel (Monterey: BrooksCole, 1979), 34-38.

27"Helsingin kalasataman romanit saivat taas jatkoajan", Iltalehti 28.03.2011; "Poliisille virkaapupyyntö romanikerjäläisten poistamiseksi", Ilta-Sanomat 31.03.2011;"Helsinki hakee romanileirille vaihtoehtoa - Vuokrasopimus yritetään purkaa", Iltalehti 11.04.2011; "Tästä syystä huijarit kauppaavat kiikareita - varo!", Ilta-Sanomat 21.07.2011; "Espanja sai luvan rajoittaa romanialaisten palkkaamista", Iltalehti 12.08.2011; "Omakaupunki: Romanien 102 
Beggars allegedly earned large sums of money, which exceeded the "honest work" of Finns. Impressive reports that stirred people up regarding individual events such as fights between beggars, or "territorial ("turf") struggles" were also reported.28 During 2011, the whole image regarding begging began to form: begging was a case of fraud. In reality, beggars were not actually people in need, but they were just acting this to arouse pity and a desire to help in Finns.

That described above, the focus on abuses that angered ordinary people, the dramatic presentation of financial abuses, the emphasis on lawlessness and the morally questionable behaviour brought forth for people to feel terrible about was perhaps what could be expected of the journalism of the "yellow press". However, a comparison of the tabloid writing to that of the Turun Sanomat shows that presenting the issue of the Roma in a negative light was not only characterized by the exaggeration of scandals in tabloids. The same detected and rumoured abuses have also dominated the articles of the Turun Sanomat during 2011.29 As the quantitative analysis shows, the negative articles in the material of the Turun Sanomat have clearly increased to be the largest writing category during 2011, at the expense of neutral and positive news.

The matter must be interpreted such that beginning in the last months of 2010, the last period examined, the residency-related problems of the Roma in Finland have generally turned the attitude of journalists against the Roma. This analysis is confirmed by including a fourth

tölkinkeräys hämmästyttää - katso kuvalinkki", Ilta-Sanomat 28.08.2011; "BBC:n tutkivat journalistit seurasivat vuoden ajan: Romanikerjäläiset tekevät hirmutiliä", Ilta-Sanomat 21.10.2011.

28 "IL Romaniassa: Näin Suomessa kerjäävät elävät kotimaassaan", Iltalehti 7.01.2011; "Verinen riita kerjuupaikasta - kävelykeppi viuhui", Ilta-Sanomat 3.06.2011; "Poliisi poisti kivittäjäromaneita leiristä Helsingissä", Ilta-Sanomat 10.06.2011; "Tappelun raju motiivi Helsingin asemalla: 'Helsinki on Romanian romanien etupiiriä'", Ilta-Sanomat 17.10.2011; "Pidätetyt romanialaiset vaativat kynnysrahaa Helsingissä oleskelusta", Ilta-Sanomat 18.10.2011; "Joukkotappelun uhrit: Meiltä vaadittiin rahaa Helsingissä oleskelusta", Iltalehti 18.10.2011.

29 "Kerjäläiset eivät lähteneetkään Kalasatamasta", Turun Sanomat 30.03.2011; "Poliisille virka-apupyyntö romanikerjäläisten poistamiseksi", Turun Sanomat 1.04.2011; "Poliisi: Riitaa kerjuupaikasta ratkottiin kävelykepillä Helsingissä", Turun Sanomat 3.06.2011; "Katukerjäläisillä verinen reviiritaistelu Helsingissä", Turun Sanomat 3.06.2011; "Romanit eivät totelleet siirtokäskyä", Turun Sanomat 10.06.2011; "Romanikerjäläiset käyttivät turkulaisyritystä käymälänä viikkokausia", Turun Sanomat 2.09.2011; "Romanialaisia epäillään reviiritappelusta Helsingissä", Turun Sanomat 17.10.2011 
newspaper in the comparison - the Kaleva, which appears in Oulu, and which is sixth in terms of the circulation statistics of Finnish newspapers (over 78,000), immediately after the Iltalehti. ${ }^{30}$ From 2008-2011 the Kaleva has published a total of 38 news articles concerning the Roma. Their intensity and tone profiles are similar to that of the Turun Sanomat. For instance, during 2008, of nine articles published, only one ${ }^{31}$ was clearly negative, while there were four ${ }^{32}$ sympathetic articles and four ${ }^{33}$ which could be counted as neutral. Out of eight articles published in 2011, four ${ }^{34}$ were negative, three ${ }^{35}$ were neutral and only one ${ }^{36}$ was sympathetic. In other words, the overall tone has been almost exactly the opposite in comparison to 2008.

30 (Circulation statistics in Finland 2010) "Suomen 10 suurinta sanomalehteä levikin mukaan," http:/ / www.sanomalehdet.fi/index.phtml?s=119, accessed 22.11.2011.

31 "Kerjäläisistä tuli riesa", Kaleva 14.04.2008.

32 "Romanit vaativat loppua vainolle Italiassa", Kaleva 8.06.2008; "EU haluaa kitkeä romanien syrjintää", Kaleva 2.07.2008; "EN huolissaan Italian romanien kohtelusta", Kaleva 29.07.2008; "Maahanmuuttajien työllistyminen toisi miljoonasäästöt", Kaleva 2.10.2008.

33 "Romanin vaikea saada turvapaikkaa Suomesta", Kaleva 25.06.2008; "Romaneita majoittunut Rastilan leirintäalueelle", Kaleva 16.07.2008; "Romanien köyhyys käy kalliiksi EU:lle", Kaleva 5.08.2008; "Helsinkiin tuli odotettua vähemmän kerjäläisiä", Kaleva 14.08.2008.

34 "Pakkastalvi ja lähtöraha ajoivat kerjäläisiä kotiin", Kaleva 17.01.2011; "Kerjäläiset eivät lähteneetkään Kalasatamasta", Kaleva 30.03.2011; "Katukerjäläisillä verinen reviiritaistelu Helsingissä", Kaleva 3.06.2011; "Romanialaisia epäillään reviiritappelusta Helsingissä", Kaleva 17.10.2011.

35 "Kalasataman romanit saivat taas lisäaikaa", Kaleva 28.03.2011; "Poliisi häätää taas romaneja Helsingissä", Kaleva 14.06.2011; "Romanit poistuivat Senaatintorilta", Kaleva 31.08.2011.

36 "Romanit saavat olla Kalasatamassa yli viikonlopun", Kaleva 24.03.2011. 
Chart 7: Yearly distribution of writings according to the tone towards the Roma in Kaleva

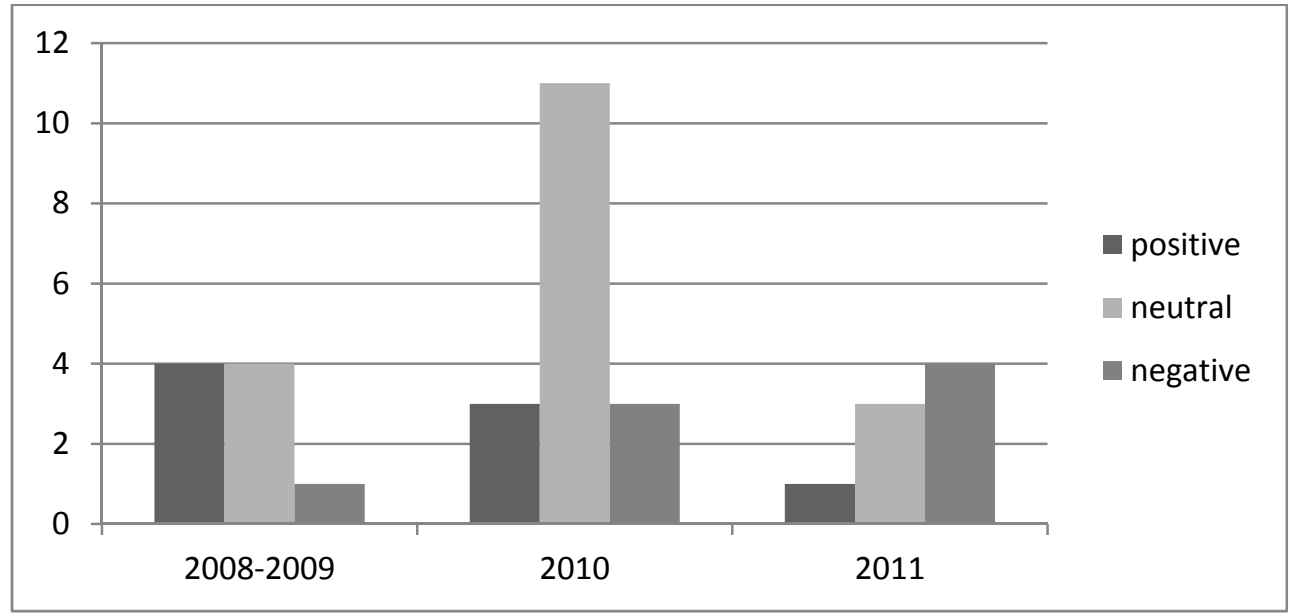

It appears that in "normal" Finnish newspapers, there has long been a desire to understand the Roma and that even in problematic situations, there has been a desire to shed light on the issue from both sides. Discrimination against the Roma has not been accepted and it has been considered necessary to examine how their situation could be improved. Particularly when the issue has been about the treatment of Roma in other parts of Europe, attitudes towards the Roma have even been sympathetic. However, this kind of understanding has no longer been sufficient from the fall of 2010 onwards, when there has been more and more knowledge of negative phenomena that are related to the residency of Roma in Finland. That which has been regarded from a distance (for example in France) has not been considered too distracting, yet it has exceeded the threshold of tolerance when it has occurred in the home environment. Of course, it is easier to tolerate difference if it does not interfere with one's everyday life. When, however the way of life of Roma has differed from Finnish behavioural norms and has constantly led to ever-worsening conflicts on different levels in Finland, the attitude aspiring towards understanding has apparently changed to one of disappointment and counter-reaction. In this case, negative emotions are easily emphasized, which is also indicated by the fairly sharp change in tone in all of the newspapers examined. 
In any case, on the basis of the material examined, tabloids differ from conventional newspapers in the sense that in them, negative news regarding the Roma has been more apparent the whole time. The earlier a period is examined, the greater the difference is, and by the time one examines the situation in 2011, the differences have almost disappeared. Tabloids have also always been more interested in events that have just occurred and in individual events that awake attention. They have had less interest in an analysis of background information, and when there have been no particularly interesting things relating to the Roma, the subject has in practice completely disappeared from the columns of tabloids for months. The very little writing done in 2009 is the clearest example of this.

\section{Conclusion}

The image created of Roma in Finnish tabloid newspapers (and to a large extent in Turun Sanomat and Kaleva also during 2011) from 20082011 can be summed up as follows: the Roma are a strange, clearly different group from the Finns, a typical representative of "otherness". This difference consists of practicing pursuits of livelihood which are foreign in Finland; begging and street selling, and in addition, Roma are widely seen to violate the laws of Finland as well as moral values and manners. Straightforward criminality and general dishonesty are also essential to the tabloid image of the Roma. It is true that at no one point has this image been one dimensional, but column space has also been given to those voices that have tried to help the Roma. Discrimination against the Roma in various parts of Europe has also been revealed. However, editors have not chosen articles that have actively defended the Roma, and particularly in the case of events in Finland, the general impression given by the news is that the Roma have mainly themselves to blame for the difficulties they encounter and for the rejection and suspicion they encounter in Finns.

During the whole media debate examined, the media has repeatedly brought forth the fact that the Roma coming to Finland have almost exclusively been from Romania. As a complementary perspective of this analysis, we can assess what kind of significance the debate in issues regarding the Roma in the Finnish tabloids from 2008-2011 has had on the image mediated of Romania. During the four years mentioned, the IltaSanomat has published 329 articles in which Romania is presented in one way or other. The corresponding number for the Iltalehti is 259. In these 
articles, in the Ilta-Sanomat, Roma are the subject in 104 cases and in the Iltalehti, in 40 cases. Mechanically calculated, the proportion of Roma from all of the Romania related articles of the Ilta-Sanomat is thus thirty-two percent, and in the case of the Iltalehti, around fifteen percent. However, further examining the news distribution reveals that the Roma theme is much larger for the whole image of Romania and in practice, in both papers, it dominates.

In both tabloids, the largest Romania related subject is sports. In the Ilta-Sanomat it accounts for approximately forty percent of all the news in which Romania is mentioned, and in the Iltalehti, almost sixty percent. In almost all of these, the case is of sporting results in which Romania is only mentioned in passing as the home country of an individual athlete or team. In the case of the image mediated of Romania to readers, it is unlikely that this has as much significance as the theoretical number of news reports relates: mostly the case is only of an individual Romanian athlete in a long list of results. Secondly, about ten percent of Romania related news in both papers is related to the Eurovision song contest and even in these articles, the Romanian representative is only mentioned in passing. Thus, the room left for all other articles related to Romania in the Ilta-Sanomat is only a twenty percent share, and the corresponding proportion for the Iltalehti is about fifteen percent.

"Other topics" are naturally divided into a variety of topics concerning economics, politics, and culture. If the image of Romania offered to readers of Finnish tabloids from the years 2008-2011 is slightly simplified, the elements of the image can be defined as the following, in order of importance: 1) There is a large group of Romanian Roma beggars who have come to Finland, who are discriminated against in Europe and who, when they are in Finland, support themselves by begging and illegal peddling, and who have caused many kinds of disturbances and problems; 2) Romanian athletes have attended international sports competitions with varying degrees of success; 3) Romania has participated in Eurovision song contests, with varying degrees of success; 4) Other, random events related to different areas of life (maybe difficult to recall at all due to their low number and sporadic nature).

Parallel equations cannot be drawn between the information offered and the information and images adopted by readers. However, it can be noted that the image offered of Romania by Finnish tabloids has been 
centered on the Roma and the problem of the Roma. In this sense, Romania may have a slight reason for worry in the case of the country's image. On the other hand, it is questionable whether it is possible to change this image even with any kinds of active promotional campaigns. Although the Romanian government and other quarters sympathetic to Romania would strive to present tabloids with consciously created, more diverse and more positive material regarding Romania, it is unlikely that the newspapers would accept it in any other form besides that of paid advertising. The actual selection and tone of writing is based on other reasons. Bad news, threats, dramas and scandals are better selling subjects than positive descriptions of how, in various areas of life, the basics of life progress steadily and in essence, they go at least fairly well. This goes for all the press, but especially, for the tabloid press.

\section{References:}

Council of Europe: Commissioner for Human Rights, Recent Migration of Roma in Europe, 10 December 2008, http://www.unhcr.org/refworld/docid/4a703c2a2.html, accessed 30.03.2012.

Gergen, Kenneth J. and Gergen, Mary M. Social psychology. New York: Springer, 1986.

Iltalehti 2004-2011.

Ilta-Sanomat 2004-2011.

Kaleva 2008-2011.

“Kerjäläisten määrä lähes entisellään”, Helsingin Sanomat 4.06.2009.

Sisäministeriö. Kerjäämisen kieltämistä selvittävä työryhmä. Loppuraportti, http:/ / www.intermin.fi/intermin/ biblio.nsf/A76D52A8F876DE07 C22577B4001BCE18/\$file/312010.pdf, accessed 30.03.2012.

Ratz, David. "The Study of Historical Images", Faravid 31 (2007): 189-220. Sparks, Colin. "Introduction. The Panic over Tabloid News." In Tabloid Tales. Global Debate over Media Standards, eds. Colin Sparks and John Tullock. Lanham: Rowman \& Littlefield, 2000, 1-40.

"Suomen 10 suurinta sanomalehteä levikin mukaan," http:/ / www.sanomalehdet.fi/index.phtml?s=119, accessed 22.11.2011. 
Tajfel, Henry and Turner, John. "An Integrative Theory of Intergroup Conflict." In The Social Psychology of Intergroup Relations, ed. W. G. Austin \& S. Worchel. Monterey: Brooks-Cole, 1979, 33-47.

Turun Sanomat 2004-2011.

Wasserman, Herman. African Expressive Cultures. Tabloid Journalism in South Africa: True Story! Bloomington: Indiana University Press, 2010. 